\title{
Studi tentang negara Pancasila sebagai Darul Ahdi Wa Syahadah untuk penguatan materi pembelajaran Pendidikan Kewarganegaraan di Universitas Ahmad Dahlan
}

\author{
Dikdik Baehaqi Arif dan Syifa Siti Aulia \\ Universitas Ahmad Dahlan \\ dikdikbaehaqi@ppkn.uad.ac.id
}

\begin{abstract}
Abstrak
This research-based article tries to dig the conception of Pancasila-based State as Darul Ahdi Wa Syahadah to enlarge and enrich teaching materials of Citizenship Education for students at Muhammadiyah Higher Education. It is argued that this effort is to give them basic comprehension of conceptual as well as practical dimensions of the relation among state, Pancasila, and Islam in accordance with Muhammadiyah doctrine. Unit of analysis is the coordinators of Citizenship Education at Ahmad Dahlan University. Data was collected through interview and document reading. Interviewees were coordinators and lecturers of the program chosen purposively. It is argued that the urgency of conception of Pancasila-based State as Darul Ahdi Wa Syahadah to strengthen and enlarge teaching materials of Citizenship Education at Ahmad Dahlan University due to its accordance with its vision and mission as an institution under Muhammadiyah Higher Education Foundation.

Keywords: Islam, Pancasila-based state, Darul Ahdi Wa Syahadah, Citizenship Education, Muhammadiyah higher education
\end{abstract}

\section{Pendahuluan}

Berbagai penelitian yang mengangkat tema Pancasila, Islam, relasi masyarakat Islam dan negara, Pancasila dan Islam, Filsafat Pendidikan Muhammadiyah, maupun Pendidikan Kewarganegaraan di Perguruan Tinggi Muhammadiyah, telah banyak dilakukan. Namun demikian, penelitian yang mengangkat konsep Negara Pancasila sebagai Darul Ahdi Wa Syahadah belumlah banyak dilakukan.

Sekalipun demikian, ikhtiar untuk melakukan penelitian dan/atau kajian lanjut tentang Negara Pancasila sebagai Darul Ahdi Wa Syahadah yang merupakan wujud komitmen kebangsaan Muhammadiyah tersebut telah dilakukan oleh Baidhawy (2015) yang dengan tegas menyebut negara Pancasila sebagai negara syariat. Baidhawy (2015) menawarkan alternatif pemaknaan mengenai konsep negara dalam bingkai Islam dan bingkai Pancasila, dan mengemukakan suatu formula baru memahami "negara syariat" sesuai dengan konteks ke-Indonesiaan. Dalam pandangan Baidhawy (2015), kajiannya tersebut secara praktis bisa menjadi tawaran untuk membumikan visi profetik yang lugas dan cerdas dari Pancasila sebagai jalan keluar dari kegamangan dan krisis kepercayaan sebagian umat Islam di negeri ini.

Sebelum kajian yang dilakukan Baidhawy, pemahaman tentang negara syariat sesuai konteks ke-Indonesia-an telah dengan lugas dikaji dalam disertasi yang kemudian menjadi buku referensi utama tentang Islam Syariat, yang ditulis oleh Nashir (2013). Dalam kajiannya tersebut, Nashir (2013) secara cermat menelaah upaya kelompokkelompok Islam yang berjuang untuk menegakkan syariat Islam sebagai dasar negara Indonesia dan perjuangan menggantikan NKRI dengan khilafah 
Islamiyah, terutama di awal-awal reformasi Indonesia.

Tawaran yang diajukan Baidhawy (2015) tentang alternatif pemaknaan mengenai konsep negara dalam bingkai Islam dan bingkai Pancasila, serta pemahaman yang cermat tentang Islam Syariat sebagaimana dikemukakan Nashir (2013) tersebut, dapat dijadikan pijakan awal bagi penelitian yang fokus membahas relasi Islam, Pancasila, dan NKRI. Dalam konteks penelitian ini, kedua kajian tersebut menjadi sumber literatur dalam penelitian ini, selain Tanfidz Keputusan Muktamar Muhammadiyah ke-47 di Makasar tentang Negara Pancasila sebagai Darul Ahdi Wa Syahadah.

Sejak awal berdiri, persyarikatan Muhammadiyah telah berkiprah melewati berbagai fase zaman yang sarat dinamika yang dihadapi dengan penuh keikhlasan dan perjuangan tanpa kenal lelah. Dalam kehidupan kebangsaan, khususnya pada era reformasi, rumusan Pernyataan Pikiran Muhammadiyah Abad Kedua menyebut bahwa Muhammadiyah menjadi pilar penting masyarakat madani (civil society) dan memelopori era baru Indonesia yang demokratis, menghargai hak asasi manusia, berwawasan kemajemukan, serta bersikap responsif dan kritis kepada pemerintah sesuai dengan kepribadian Muhammadiyah. Bagi Nashir (2016), pandangan kebangsaan Muhammadiyah tersebut menegaskan komitmen tentang Negara Kesatuan Republik Indonesia yang berdasarkan Pancasila dan UUD 1945 serta konsisten dalam mengintegrasikan ke-Islam-an dan keIndonesia-an.

Rumusan Pernyataan Pikiran Muhammadiyah Abad Kedua tersebut, seyogianya menjadi alam pikiran setiap anggota persyarikatan, lebih-lebih pimpinan, aktivis, kader, serta pelaksana amal usaha Muhammadiyah di berbagai aspek. Dari sisi pendidikan tinggi, penegasan komitmen kebangsaan Muhammadiyah perlu direspon positif oleh seluruh penyelenggara dan insan akademika di lingkungan pendidikan tinggi Muhammadiyah/Aisyiyah. Komitmen itu harus mewujud pada segenap aktivitas sivitas akademika kampus Muhammadiyah/Aisyiyah, termasuk mahasiswa. Tidak ada proses yang paling penting, melainkan melalui pendidikan dan pembelajaran.

Penyelenggaraan Perguruan Tinggi Muhammadiyah mengemban misi dakwah Islam amar ma'ruf nahi munkar. Misi itu menjadi bagian penting dalam upaya pencerdasan kehidupan bangsa. Karena itu, seluruh aktivitas pembelajaran di lingkungan Perguruan Tinggi Muhammadiyah/Aisyiyah harus dapat menjunjung dan menguatkan misi tersebut. Jika lahir dari setiap kampus pemikiran dan penguatan atas komitmen kebangsaan itu, maka harapan pengintegrasian ke-Islam-an dan keIndonesia-an tentu tidak akan mendapat kendala berarti.

Untuk memperkuat komitmen kebangsaan itu, telah pula dirumuskan satu pernyataan monumental tentang komitmen kebangsaan Muhammadiyah, yaitu rumusan tentang Negara Pancasila sebagai Darul Ahdi Wa Syahadah pada Muktamar Muhammadiyah ke-47 di Makasar tahun 2015 yang lalu. Konsep ini sesungguhnya menegaskan komitmen ke-Islam-an dan keIndonesia-an yang dipahami Muhammadiyah. Karena itu, perlu terus disebarluaskan kepada segenap warga persyarikatan Muhammadiyah khususnya, maupun kepada khalayak umum warga negara Indonesia melalui berbagai cara, termasuk melalui proses pendidikan dan 
pembelajaran. Gerakan pendidikan dalam persyarikatan Muhammadiyah telah dikenal lama memberikan kontribusi besar bagi Indonesia, mulai dari pendidikan usia dini hingga perguruan tinggi.

Dalam hubungannya dengan negara dan bangsa Indonesia, Muhammadiyah sebagai organisasi gerakan dakwah Islam amar ma'ruf nahi munkar adalah bagian integral dari bangsa Indonesia. Karena itu, Muhammadiyah akan berusaha untuk senantiasa berusaha dengan segala kekuatan yang dimiliki untuk membangun Indonesia sebagai komitmen ke-Indonesian dan sebagai wujud pengamalan agama Islam menurut paham agama Muhammadiyah.

Komitmen kebangsaan Muhammadiyah tentang Negara Pancasila sebagai Darul Ahdi Wa Syahadah telah secara tegas disusun dan dibahas dalam Muktamar Muhammadiyah ke47 di Makasar 2015 yang lalu. Keputusan Muktamar yang tertuang dalam Tanfidz Keputusan Muktamar Muhammadiyah ke-47 tersebut kini dibukukan menjadi Negara Pancasila sebagai Darul Ahdi Wa Syahadah yang diterbitkan Penerbit Suara Muhammadiyah pada tahun 2015.

Pandangan Negara Pancasila sebagai Darul Ahdi Wa Syahadah, berangkat dari tiga latar belakang utama. Pertama, adanya kelompok-kelompok atau beberapa elemen masyarakat, terutama masyarakat muslim yang masih mempersoalkan relasi antara Islam dengan negara, dan mempersoalkan negara Indonesia yang berdasarkan Pancasila. Kedua, adanya realitas bahwa sebagai bangsa ini secara ideologis belum merumuskan dengan sangat eksplisit dan membuat satu penjelasan akademik mengenai negara Pancasila itu. Ketiga, ada sebuah realitas dimana masyarakat Islam dianggap sebagai ancaman terhadap negara Pancasila itu (Mu'ti,
2015). Terkait dengan tiga realitas inilah kemudian Muhammadiyah perlu membuat suatu pernyataan bahwa secara organisasi Muhammadiyah menerima Pancasila sebagai bentuk ideal, baik yang bersifat filosofi maupun ideologis. Bahkan juga secara konstitusional dalam hal berbangsa dan bernegara.

Dalam konteks pembelajaran, gagasan tentang negara Pancasila sebagai Darul Ahdi Wa Syahadah di perguruan tinggi Muhammadiyah perlu dikuatkan melalui mata kuliah Pendidikan Kewarganegaraan. Pilihan pada mata kuliah Pendidikan Kewarganegaraan, karena secara imperatif mata kuliah ini merupakan muatan kurikulum wajib di setiap perguruan tinggi dan pada pengembangan materinya hanya berbentuk kajian secara umum belum membahas mengenai gagasan tentang Negara Pancasila sebagai Darul Ahdi Wa Syahadah.

Upaya penguatan kajian Negara Pancasila tersebut, belum banyak dilakukan oleh para dosen Pendidikan Kewarganegaraan di lingkungan Perguruan Tinggi Muhammadiyah. Sekalipun demikian, dalam bentuk buku ajar, sejak 2002, ikhtiar untuk itu telah dirintis oleh Lembaga Pengembangan Penelitian, Publikasi dan Pengabdian Masyarakat (LP3M) Universitas Muhammadiyah Yogyakarta yang menerbitkan buku Pendidikan Kewarganegaraan yang di dalamnya juga menambahkan nilai-nilai Muhammadiyah dan ke-Islam-an, sehingga para pembaca dan mahasiswa dapat menginternalisasikan nilainilai kewarganegaraan dengan tetap berlandaskan pada nilai-nilai Islam (UMY, 2015). Buku yang telah mengalami dua kali revisi tersebut, digunakan oleh Universitas Muhammadiyah Surakarta, Universitas 
Muhammadiyah Malang, dan Universitas Muhammadiyah Surabaya.

Selain buku yang disusun oleh LP3M UMY tersebut, Universitas Muhammadiyah Purwokerto, juga telah menerbitkan buku Pendidikan Kewarganegaraan yang bermuatan nilai-nilai Islam, yaitu Pendidikan Kewarganegaraan di Perguruan Tinggi Muhammadiyah (Taniredja, 2010). Buku itu memuat nilai-nilai Islam, antara lain: PKn dan masyarakat madani; Pemerintahan yang bersih dan demokratis; Transformasi nilainilai demokrasi; Transformasi nilai-nilai Islam dalam keluarga; Transformasi nilainilai Islam dalam masyarakat; Islam, musyawarah, dan demokrasi; HAM perspektif Islam; Sistem ekonomi Islam; dan Prinsip-prinsip kepemimpinan dalam Islam.

Beberapa buku ajar di atas, dimaksudkan agar mahasiswa dapat menginternalisasikan nilai-nilai kewarganegaraan dengan tetap berlandaskan pada nilai-nilai Islam. Untuk memberikan pemahaman mahasiswa tentang Negara Pancasila sebagaimana dipahami Muhammadiyah, Khilmiyah (2016) menulis buku ajar Pendidikan Kewarganegaraan Menuju Indonesia Berkemajuan. Pembahasan buku ini disajikan secara utuh komprehensif mencakup empat konsensus tersebut dan ditambah tiga bab yang terkait hubungan Muhammadiyah dengan negara Pancasila, revitalisasi visi dan karakter bangsa, dan Indonesia Berkemajuan. Dalam penelusuran peneliti, baru buku Khilmiyah itulah yang secara spesifik membahas tentang Negara Pancasila dengan sasaran yang terbatas hanya pada mahasiswa UMY. Pada perguruan tinggi Muhammadiyah/Aisyiyah lainnya sosialisasi tentang Negara Pancasila tersebut belum banyak dilakukan, dan pengintegrasian konsep tersebut dalam pembelajaran
Pendidikan Kewarganegaraan juga belum dilakukan.

Berdasarkan uraian di atas, ada pertanyaan yang patut diajukan kepada para penyelenggara mata kuliah Pendidikan Kewarganegaraan di perguruan tinggi Muhammadiyah/Aisyiyah, apakah konsep Negara Pancasila sebagai Darul Ahdi Wa Syahadah, sebagaimana dirumuskan Muktamar Muhammadiyah ke-47 di Makasar 2015 lalu dipandang penting untuk diintegrasikan dalam materi pembelajaran Pendidikan Kewarganegaraan? dan bagaimanakah model pengintegrasian konsep tersebut dalam materi pembelajaran Pendidikan Kewarganegaraan?

\section{Metode}

Penelitian ini merupakan penelitian studi kasus, yang merupakan salah satu tradisi penelitian kualitatif. Merujuk pada pandangan Mulyana (2002) dan Faisal (1992), penelitian studi kasus ini akan menguraikan dan menelaah secara komprehensif dan intensif tentang Negara Pancasila sebagai Darul Ahdi Wa Syahadah dalam pembelajaran Pendidikan Kewarganegaraan di perguruan tinggi, terutama dilihat dari perspektif emik (Lincoln \& Guba, 1985), yakni pandangan dari penyelenggara mata kuliah Pendidikan Kewarganegaraan.

\section{Hasil dan Pembahasan}

Universitas Ahmad Dahlan memiliki kebijakan institusional dalam proses pengaturan mata kuliah Institusional termasuk Mata Kuliah Pendidikan Kewarganegaraan yakni melalui Badan Pengembangan Akademik (BPA) melalui Unit Pengelolaan Mata Kuliah Institusional. Secara yuridis Universitas Ahmad Dahlan merupakan perguruan tinggi Muhammadiyah yang bergerak di bidang pendidikan dalam pelaksanaan amal usaha Muhammadiyah. 
Dengan visi Universitas Ahmad Dahlan "Menjadi perguruan tinggi yang diakui secara internasional, dan dijiwai nilai-nilai Islam“. Berdasarkan hasil studi dokumentasi dan wawancara maka berkontribusi besar secara sosiologis dan filosofis pengembangan mata kuliah PKn di UAD dikembangkan dengan penguatan nilai-nilai Islam.

Bahkan dengan penguatan bunyi misi Universitas Ahmad Dahlan yakni "Mengimplementasikan nilai-nilai Islam pada semua aspek kegiatan Universitas". Maka pelaksanaan semua komponen pembelajaran di Perguruan tinggi ini tidak boleh lepas dari nilai-nilai Islam, termasuk di dalamnya mata kuliah Pendidikan Kewarganegaraan sebagai mata kuliah institusional di Universitas Ahmad Dahlan.

Secara yuridis pengembangan mata kuliah Institusional dengan nilai-nilai Islam di Universitas Ahmad Dahlan tidak bertentangan dengan isi dari Undang-Undang No 12 tahun 2012 tentang pendidikan tinggi yang berisi bahwa perguruan tinggi memiliki otonomi dalam penyusunan kurikulum perguruan tinggi. Terutama dalam Pasal 35 ayat 2 Kurikulum Pendidikan Tinggi dikembangkan oleh setiap Perguruan Tinggi dengan mengacu pada Standar Nasional Pendidikan Tinggi untuk setiap Program Studi yang mencakup pengembangan kecerdasan intelektual, akhlak mulia, dan keterampilan.

Berdasarkan hasil wawancara yang dilakukan ke beberapa narasumber bahwa terungkap kekhasan pengembangan Mata Kuliah PKn di UAD dengan penguatan nilainilai Islam sangat diperlukan untuk mendukung terlaksananya visi dan Misi UAD. Kekhasan nilai-nilai Islam dalam mata Kuliah Institusional di UAD tersebut bahkan dapat dijadikan sebagai penguat pelaksanaan kurikulum Pendidikan Tinggi berdasarkan Undang-Undang No 12 Tahun 2012 tentang Pendidikan Tinggi bahwa kurikulum perguruan tinggi di dalam program studi tidak boleh dilepaskan dari pembentukan akhlak mulia.

Berdasarkan hasil analisis wawancara dan studi dokumentasi didapatkan data penelitian bahwa pelaksanaan mata kuliah pendidikan kewarganegaraan di UAD memiliki kualifikasi dosen pengampu pendidikan kewarganegaraan dengan latar belakang keilmuan sebagai berikut:

1. Dosen dengan ijazah magister (S2) Ilmu Sosial

2. Dosen dengan ijazah magister (S2) Ilmu Hukum

3. Dosen dengan ijazah magister (S2) Pendidikan Kewarganegaraan

4. Dosen dengan ijazah magister (S2) Filsafat

Latar belakang dosen pengampu dengan keilmuannya tersebut di atas dapat memberikan potensi terlaksananya mata kuliah Pendidikan Kewarganegaraan dengan baik sesuai dengan Keputusan Dirjen Dikti No 43/Dikti/Kep/2006 Pasal 10 Ayat (2) ditentukan bahwa persyaratan dosen mata kuliah pengembangan kepribadian untuk Pendidikan Kewarganegaraan, yaitu (1) Dosen berijazah Magister (S2) Ketahanan Nasional. dan Magister (S2) Pendidikan Ilmu Sosial, Ilmu-ilmu Sosial, Budaya, Filsafat.

Pengembangan mata kuliah pendidikan kewarganegaraan di Universitas Ahmad Dahlan yang dikembangkan dengan penguatan nilai-nilai Islam belum diatur secara khusus kompetensi yang dapat menguatkan proses pembelajaran pendidikan kewarganegaraan dengan penguatan nilainilai Islam. 
Dosen di Universitas Ahmad Dahlan dengan kualifikasi pendidikan yang telah sesuai dengan aturan Dirjen Dikti memiliki kebebasan dalam pengembangan materi perkuliahan dengan penguatan nilai-nilai Islam sebagaimana yang diharapkan dari visi dan misi Universitas Ahmad Dahlan,

Hasil workshop penyusunan RPS dan sarana pembelajaran mata kuliah institusional yang dilaksanakan tanggal 18 Juli 2017 oleh BPA UAD didapatkan pengembangan materi pembelajaran untuk mata kuliah pendidikan kewarganegaraan dengan kajian nilai-nilai Islam terdapat dalam tiga pokok materi, antara lain:

1. Pengembangan

Pendidikan

Kewarganegaraan di Perguruan Tinggi

Muhammadiyah

2. Islam dan Nasionalisme

3. Islam dan Demokrasi

4. HAM dalam perspektif Islam

Dalam RPS yang dikembangkan untuk mata kuliah PKn di perguruan Tinggi Muhammadiyah terdapat dua hal yang menempatkan Pancasila sebagai bahan kajian antara lain mengenai Nilai-nilai Pancasila sebagai Orientasi PKn di Perguruan Tinggi dan hakikat demokrasi Indonesia yang berdasarkan Demokrasi Pancasila. Namun hakikatnya berdasarkan beberapa hasil wawancara terhadap dosen pengampu mata kuliah pendidikan kewarganegaraan bahwa Pancasila merupakan bagian yang tidak dapat dilepaskan dari penguraian materi pendidikan kewarganegaraan, setiap capaian pembelajaran Pendidikan kewarganegaraan yang diharapkan tercapai bagi mahasiswa berkaitan dengan nilai-nilai Pancasila terutama diuraikan dalam proses pembelajaran.
Konsep Negara Pancasila dalam kajian Islam terutama Muhammadiyah dalam bentuk Darul Ahdi Wa Syahadah dimaknai penting untuk dikembangkan di Perguruan Tinggi Muhammadiyah termasuk Universitas Ahmad Dahlan karena ciri khas Universitas Ahmad Dahlan sebagai perguruan tinggi yang merupakan bagian dari amal usaha Muhammadiyah sudah sepatutnya mengembangkan nilai-nilai Islam sesuai dengan visi nya dalam setiap proses pembelajaran termasuk pengembangan materi pembelajaran PKn.

Pandangan Negara Pancasila sebagai Darul Ahdi Wa Syahadah, berangkat dari tiga latar belakang utama. Pertama, adanya kelompok-kelompok atau beberapa elemen masyarakat, terutama masyarakat muslim yang masih mempersoalkan relasi antara Islam dengan negara, dan mempersoalkan negara Indonesia yang berdasarkan Pancasila. Kedua, adanya realitas bahwa sebagai bangsa ini secara ideologis belum merumuskan dengan sangat eksplisit dan membuat satu penjelasan akademik mengenai negara Pancasila itu. Ketiga, ada sebuah realitas dimana masyarakat Islam dianggap sebagai ancaman terhadap negara Pancasila itu (Mu'ti, 2015). Terkait dengan tiga realitas inilah kemudian Muhammadiyah perlu membuat suatu pernyataan bahwa secara organisasi Muhammadiyah menerima Pancasila sebagai bentuk ideal, baik yang bersifat filosofi maupun ideologis. Bahkan juga secara konstitusional dalam hal berbangsa dan bernegara.

Darul Ahdi dimaknai sebagai negara kesepakatan. Dalam hal ini, Muhammadiyah menegaskan bahwa adanya negara Pancasila itu merupakan satu produk dari kesepakatan atau satu kompromi dari para tokoh pendiri bangsa. Sehingga adanya Indonesia ini 
merupakan satu hasil dari gentlemen agreement dari para pendiri bangsa, terutama mereka yang secara langsung terlibat dalam proses-proses penyusunan dasar negara dan undang-undang dasar, baik dalam lembaga BPUPKI maupun lembaga PPKI. Dan kesepakatan itulah yang melahirkan Indonesia seperti sekarang ini.

Oleh karena itu, Muhammadiyah dan warganya sebagai bagian dari masyarakat dan bangsa Indonesia memiliki komitmen untuk tetap menjaga agreement itu. Tetap patuh terhadap kesepakatan-kesepakatan yang dibuat oleh para pendiri bangsa dalam hubungannya dengan bentuk negara kita yaitu Negara Kesatuan Republik Indonesia.

Untuk menjaga komitmen dari Muhammadiyah itu, maka Muhammadiyah harus terlibat di dalam proses-proses yang berkaitan dengan bagaimana membangun Indonesia ini, bagaimana memajukan bangsa ini. Langkah tersebut bisa dalam bentuk peran serta yang bersifat partisipatif melalui kegiatan-kegiatan yang diselenggarakan oleh Muhammadiyah, baik melalui amal-amal usaha yang dimiliki maupun dalam bentuk keterlibatan para kader maupun tokoh Muhammadiyah dalam pengambilan keputusan kenegaraan maupun dalam hal-hal yang bersifat sosial kemasyarakatan.

Sedangkan konsep darus syahadah (negara persaksian) dipahami Mu'ti (2015) dalam tiga pandangan. Pertama, Muhammadiyah dengan karakteristiknya yang ada berusaha untuk menjadikan dirinya sebagai uswah atau sebagai model yang bisa menjadi referensi bagi masyarakat. Dengan penegasan Indonesia sebagai darus syahadah atau negara yang disaksikan, Muhammadiyah ingin menunjukkan bahwa dengan ajaran Islam yang berkemajuan, Muhammadiyah bisa menggiringnya ke dalam negara Indonesia yang berkemajuan. Islam merupakan faktor determinan yang menentukan karakter ke-Indonesia-an, karena mayoritas bangsa Indonesia ini adalah umat Islam.

Kedua, bahwa karakter umat Islam dan aktivitas dari ormas-ormas Islam itu ditentukan oleh bagaimana mereka memahami ajaran Islam itu sendiri. Oleh karena itu, maka langkah awal untuk menjadikan Indonesia itu sebagai Darus Syahadah dimulai dari upaya membangun mindset berpikir yang berkemajuan. Mindset itu akan sangat berpengaruh pada karakter kepribadian yang berkemajuan, yang secara kultural akan memiliki implikasi sosiologis yang luas terhadap terbentuknya komunitas di tengah masyarakat yang berkemajuan.

Ketiga, selain yang sifatnya kultural, Muhammadiyah juga ingin terlibat dalam proses-proses yang berkaitan dengan penyusunan undang-undang atau pelaksanaan dari undang-undang dan peraturan-peraturan lain yang berhubungan dengan tata kelola penyelenggaraan negara maupun yang berhubungan dengan pembangunan moral atau karakter bangsa.

Model pengintegrasian konsep negara Pancasila sebagai Darul Ahdi Wa Syahadah dalam materi pembelajaran Pendidikan Kewarganegaraan di Universitas Ahmad Dahlan menjadi hal yang penting dikarenakan secara institusional UAD memiliki tanggung jawab untuk mengembangkan proses pembelajaran dengan penguatan nilai-nilai Islam.

Sehingga dari hasil kajian studi dokumentasi dan hasil wawancara tergambarkan sebagai berikut: 
Tabel Integrasi Konsep Negara Pancasila sebagai Darul Ahda Wa Syahadah

\begin{tabular}{|c|c|}
\hline Materi Pembelajaran & $\begin{array}{l}\text { Integrasi Konsep Negara Pancasila } \\
\text { Sebagai Darul Ahdi Wa Syahadah }\end{array}$ \\
\hline $\begin{array}{l}\text { 1. Latar Belakang dan Tujuan } \\
\text { Pembelajaran PKn di Perguruan Tinggi } \\
\text { 2. Nilai-nilai Pancasila sebagai Orientasi } \\
\text { PKn di Perguruan Tinggi } \\
\text { 3. Pembelajaran PKn di PTM }\end{array}$ & $\begin{array}{l}\text { Materi ini dapat dikembangkan dengan } \\
\text { penguraian Konsep Negara Pancasila sebagai } \\
\text { Darul Ahdi, bahwa Pendidikan } \\
\text { Kewarganegaraan menjadi media untuk } \\
\text { memahami Konsep Negara Pancasila sebagai } \\
\text { sebuah agreement yang harus dipatuhi oleh } \\
\text { setiap lapisan masyarakat }\end{array}$ \\
\hline $\begin{array}{l}\text { 1. Pengertian identitas nasional } \\
\text { 2. Sejarah kelahiran paham nasionalisme } \\
\text { Indonesia } \\
\text { 3. Identitas nasional sebagai karakter } \\
\text { bangsa } \\
\text { 4. Islam dan Nasionalisme } \\
\text { 5. Globalisasi dan tantangan identitas } \\
\text { nasional }\end{array}$ & $\begin{array}{l}\text { Pemahaman identitas nasional dalam materi } \\
\text { ini dapat dikembangkan dengan memaknai } \\
\text { identitas nasional Indonesia salah satu } \\
\text { bentuknya adalah kesepakatan semua pihak } \\
\text { mengenai keberadaan Pancasila yang tinggal } \\
\text { dipatuhi oleh semua elemen masyarakat. }\end{array}$ \\
\hline $\begin{array}{l}\text { 1. Hakikat konstitusi } \\
\text { 2. Urgensi konstitusi bagi kehidupan } \\
\text { bernegara }\end{array}$ & $\begin{array}{l}\text { Dalam Darus Syahadah (negara persaksian) } \\
\text { elemen ketiga yakni warga negara dapat ikut } \\
\text { terlibat aktif untuk pelaksanaan konstitusi di } \\
\text { Negara Indonesia. }\end{array}$ \\
\hline $\begin{array}{l}\text { 1. UUD } 1945 \text { sebagai Konstitusi Indonesia } \\
\text { 2. Dinamika dan tantangan konstitusi di } \\
\text { Indonesia } \\
\text { 3. Perilaku konstitusional warga negara }\end{array}$ & \\
\hline $\begin{array}{l}\text { 1. Hubungan negara dan warga negara } \\
\text { 2. Peranan warga negara }\end{array}$ & $\begin{array}{l}\text { Memahami peranan warga negara selain } \\
\text { secara konstitusional dapat diuraikan konsep } \\
\text { negara Indonesia sebagai Darus Syahadah } \\
\text { dengan bentuk karakter warga negara yang } \\
\text { berkemajuan yang berkontribusi aktif untuk } \\
\text { kehidupan masyarakat. }\end{array}$ \\
\hline $\begin{array}{l}\text { 1. Hak dan kewajiban warga negara } \\
\text { 2. Dinamika dan tantangan pelaksanaan } \\
\text { hak dan kewajiban warga negara }\end{array}$ & $\begin{array}{l}\text { Memahami hak dan kewajiban warga negara } \\
\text { selain secara konstitusional dapat diuraikan } \\
\text { konsep negara Indonesia sebagai Darus } \\
\text { Syahadah dengan bentuk karakter warga } \\
\text { negara yang berkemajuan yang berkontribusi } \\
\text { aktif untuk kehidupan masyarakat. }\end{array}$ \\
\hline
\end{tabular}




\begin{tabular}{|c|c|}
\hline Materi Pembelajaran & $\begin{array}{l}\text { Integrasi Konsep Negara Pancasila } \\
\text { Sebagai Darul Ahdi Wa Syahadah }\end{array}$ \\
\hline $\begin{array}{l}\text { 1. Makna dan prinsip demokrasi } \\
\text { 2. Hakikat demokrasi Indonesia (demokrasi } \\
\text { Pancasila) } \\
\text { 3. Islam dan demokrasi } \\
\text { 4. Dinamika dan tantangan Demokrasi di } \\
\text { Indonesia }\end{array}$ & $\begin{array}{l}\text { Prinsip demokrasi yang berlandaskan } \\
\text { Pancasila dapat dikembangkan dengan } \\
\text { penguraian materi untuk memahami } \\
\text { Pancasila sebagai sebuah kesepakatan untuk } \\
\text { membentuk Darul Ahdi. Sehingga } \\
\text { pelaksanaan demokrasi di Indonesia tidak } \\
\text { terlepas dari nilai-nilai kesepakatan yang } \\
\text { terdapat dalam Pancasila. }\end{array}$ \\
\hline $\begin{array}{l}\text { 1. Negara Hukum } \\
\text { 2. Hubungan negara Hukum dan HAM } \\
\text { 3. Prinsip negara hukum dalam kehidupan } \\
\text { warga negara }\end{array}$ & $\begin{array}{l}\text { Memahami konsep Indonesia sebagai Negara } \\
\text { hukum maka sebagai warga negara yang aktif } \\
\text { dalam pelaksaan Pancasila haruslah } \\
\text { menghormati dan menjunjung tinggi hukum } \\
\text { sebagai bentuk Darus Syahadah. }\end{array}$ \\
\hline $\begin{array}{l}\text { 1. HAM dalam konstitusi Indonesia } \\
\text { 2. HAM perspektif Islam } \\
\text { 3. Isu-isu aktual HAM dan Penegakan HAM } \\
\text { di Indonesia }\end{array}$ & $\begin{array}{l}\text { Memahami hak dan kewajiban warga negara } \\
\text { selain secara konstitusional dapat diuraikan } \\
\text { konsep negara Indonesia sebagai Darus } \\
\text { Syahadah dengan bentuk karakter warga } \\
\text { negara yang berkemajuan yang berkontribusi } \\
\text { aktif untuk kehidupan masyarakat. }\end{array}$ \\
\hline $\begin{array}{l}\text { 1. Wilayah sebagai ruang hidup bangsa } \\
\text { 2. Wawasan Nusantara sebagai pandangan } \\
\text { geopolitik Indonesia } \\
\text { 3. Implementasi wawasan Nusantara }\end{array}$ & $\begin{array}{l}\text { Pengembangan materi wawasan Nusantara } \\
\text { dan geopolitik dapat dikembangkan dengan } \\
\text { memahami kondisi geografis Indonesia } \\
\text { sebagai hasil sebuah kesepakatan Darul Ahdi } \\
\text { yang harus dilindungi. }\end{array}$ \\
\hline $\begin{array}{l}\text { 1. Esensi dan urgensi ketahanan nasional } \\
\text { 2. Model Ketahanan Nasional Indonesia } \\
\text { 3. Bela negara sebagai dengan pendekatan } \\
\text { astagatra } \\
\text { 4. upaya mewujudkan ketahanan nasional } \\
\text { 5. Dinamika dan tantangan ketahanan } \\
\text { nasional Indonesia }\end{array}$ & $\begin{array}{l}\text { Pengembangan materi ketahanan nasional } \\
\text { dapat dikembangkan dengan memahami } \\
\text { kondisi geografis Indonesia sebagai hasil } \\
\text { sebuah kesepakatan Darul Ahdi yang harus } \\
\text { dilindungi. }\end{array}$ \\
\hline $\begin{array}{l}\text { 1. Keanekaragaman masyarakat Indonesia } \\
\text { 2. Dinamika dan tantangan keanekaragaman } \\
\text { masyarakat Indonesia } \\
\text { 3. Strategi integrasi nasional } \\
\text { 4. Isu-isu aktual integrasi nasional }\end{array}$ & $\begin{array}{l}\text { Pengembangan materi Integrasi nasional } \\
\text { dapat dibentuk dengan memadukan materi } \\
\text { mengenai integrasi dapat terwujud apabila } \\
\text { semua elemen warga negara memahami } \\
\text { negara Pancasila sebagai Darul Ahdi Wa } \\
\text { Syahadah. }\end{array}$ \\
\hline
\end{tabular}

Sumber: Data diolah penulis, 2017) 
Metode pembelajaran yang dilaksanakan di Universitas Ahmad Dahlan dalam dokumentasi Rencana Pembelajaran Semester antara lain, sebagai berikut:

1. Curah pendapat

2. Model pembelajaran Critical Incident (pengalaman penting)

3. Kajian literatur

4. Problem solving Current Issues

5. Cooperative Learning

6. Studi kasus

Metode-metode pembelajaran tersebut menjadi metode pembelajaran yang efektif untuk mengasah berfikir mahasiswa aktif dan kreatif dalam pemahaman negara Pancasila dalam konsep Darul Ahdi Wa Syahadah dalam mata kuliah Pendidikan Kewarganegaraan di Universitas Ahmad Dahlan.

Media pembelajaran yang berbentuk audio-visual menjadi media yang menarik untuk disajikan kepada mahasiswa terutama untuk menampilkan materi-materi pembelajaran PKn yang dihubungkan dengan konsep Negara Pancasila dalam konsep Darul Ahdi Wa Syahadah

Sumber pembelajaran terutama bukubuku berkaitan tentang bagaimana Muhammadiyah memandang Negara Pancasila sebagai Darul Ahdi Wa Syahadah menjadi bahan yang banyak digunakan oleh dosen-dosen pengampu mata kuliah Pendidikan Kewarganegaraan di Universitas Ahmad Dahlan selain buku-buku yang dianjurkan Oleh Dirjen Dikti.

Evaluasi pembelajaran yang melatih mahasiswa berpikir kritis dan analitis menjadi evaluasi yang tepat dalam pengintegrasian materi PKn di UAD dengan Konsep negara Pancasila sebagai Darul Ahdi Wa Syahadah.

Pada akhirnya, Muhammadiyah sebagai kekuatan amar ma'ruf nahi munkar, sebagai kekuatan civil society Islam, melalui pendidikan melahirkan orang-orang yang memiliki komitmen: 1) mengembangkan ilmu pengetahuan dan teknologi yang berperspektif integrasi. Melalui cara ini Muhammadiyah akan memiliki ilmuwan, saintis, intelektual yang distinct; 2) memperkokoh kekuatan rasional dan kritis. Ini sangat penting antara lain untuk mengkritisi berbagai penyimpangan yang muncul di tengah-tengah masyarakat dan di kalangan penyelenggara negara yang makin nampak koruptif. Kebijakan pemerintah terkait dengan pendidikan yang tidak transparan, tidak rasional, diskriminatif dan tidak memikirkan kepentingan umum haruslah dihentikan; dan 3) memperkokoh komitmen ideologis Ke-Islam-an dan KeIndonesia-an (Hakim, 2016).

Untuk melahirkan lulusan di atas, Persyarikatan Muhammadiyah telah menetapkan Pedoman Penyelenggaraan Perguruan Tinggi Muhammadiyah (Pimpinan Pusat Muhammadiyah, 2012) agar terselenggaranya catur dharma pendidikan tinggi Muhammadiyah dalam bidang Pendidikan, Penelitian, dan Pengabdian Masyarakat, serta Al Islam dan Kemuhammadiyahan. Kesemuanya itu dimaksudkan dalam rangka mencapai tujuan pendidikan tinggi Muhammadiyah, yaitu:

1. Berkembangnya potensi manusia yang beriman dan bertaqwa kepada Allah SWT, berakhlak mulia, cerdas, berilmu, cakap, kreatif, dan mandiri sehingga terwujud masyarakat Islam yang sebenar-benarnya.

2. Terwujudnya kemampuan penciptaan, pengembangan, dan penyebarluasan ilmu pengetahuan, teknologi, dan seni yang memberikan kemaslahatan, bagi masyarakat, bangsa, negara, dan umat manusia. 
3. Terbinanya Keislaman dan Kemuhammadiyahan yang mencerdaskan dan mencerahkan bagi seluruh sivitas akademika dan kehidupan yang lebih luas. (Pimpinan Pusat Muhammadiyah, 2012) Ketiga tujuan utama pendidikan tinggi Muhammadiyah tersebut sesungguhnya meneguhkan peran Muhammadiyah dalam upaya pencerdasan kehidupan bangsa, melalui koridor ke-Islam-an dan keIndonesia-an.

\section{Simpulan}

Urgensi konsep Negara Pancasila sebagai Darul Ahdi Wa Syahadah untuk penguatan materi pembelajaran Pendidikan Kewarganegaraan di Universitas Ahmad Dahlan mejadi yang penting dalam pengembangan pembelajaran pendidikan kewarganegaraan dilandaskan pada UAD sebagai Universitas di bawah kendali amal usaha Muhammadiyah yang memiliki visi dan misi menguatkan nilai-nilai Islam. Penguatan materi pembelajaran PKn di UAD dengan konsep Negara Pancasila sebagai Darul Ahdi Wa Syahadah dapat ditambahkan untuk melengkapi materi-materi PKn sebagai mata kuliah wajib umum yang diamanatkan oleh Undang-Undang.

Model pengintegrasian konsep Negara Pancasila sebagai Darul Ahdi Wa Syahadah dalam materi pembelajaran Pendidikan Kewarganegaraan di Universitas Ahmad Dahlan dapat dilakukan dengan pengembangan setiap materi ajar Pendidikan Kewarganegaraan.

\section{Ucapan Terima Kasih}

Terima kasih penulis sampaikan kepada Lembaga Penelitian Universitas Ahmad Dahlan yang telah memfasilitasi penelitian ini dan mempercayai penulis untuk melakukan penelitian fundamental. Terima kasih juga penulis haturkan pada para responden yang berpartisipasi dalam penelitian ini.

\section{Daftar Pustaka}

Baidhawy, Z. (2015). Negara Pancasila sebagai negara syariah. MA'ARIF, 10(1), 41-57.

Ditjen Dikti. (2006). Keputusan Dirjem Dikti No 43/Dikti/2006 tentang RambuRambu Pelaksanaan Mata Kuliah Pengembangan Kepribadian di Perguruan Tinggi. Jakarta: Ditjen Dikti.

Hakim, S.A. (2016, Maret 11). Kolom: arah baru perguruan tinggi Muhammadiyah. Retrieved April 4, 2016, From Suara Muhammadiyah: Meneguhkan dan Mencerahkan: http://suara muhammadiyah.com/.

Khilmiyah, A. (2016). Pendidikan Kewarganegaraan menuju Indonesia berkemajuan. Yogyakarta: Samudra Biru.

Lincoln, Y. S., \& Guba, E. G. (1985). Naturalistic inquiry. Beverly Hills: Sage.

Mu'ti, A. (2015, Desember 28). Editorial: Dialog. Retrieved 1 23, 2017, From Suara Muhammadiyah: http://www.suaramuhammadiyah.id/2 015/12/28/masih-perlu-road-mapmengisi-negara-pancasila/.

Nashir, H. (2013). Islam syariat. Bandung: Mizan.

Nashir, H. (2016). Kuliah kemuhammadiyahan. Yogyakarta: LPSI UAD bekerja sama dengan Penerbit Suara Muhammadiyah.

Taniredja, T. (2010). Pendidikan Kewarganegaraan di perguruan tinggi Muhammadiyah. Bandung: Alfabeta.

Pimpinan Pusat Muhammadiyah. (2012). Pedoman Pimpinan Pusat Muhammadiyah No.02/PED/I.0/B/2012 Tahun 2012 tentang perguruan tinggi 
Muhammadiyah. Yogyakarta:

Pimpinan Pusat Muhammadiyah.

UMY. (2015, Oktober 10). LP3M UMY

terbitkan buku PKN berlandaskan

nilai-nilai Islam. Retrieved April 5,

2016,

from

http://www.umy.ac.id/terbitkan-

buku-pkn-berlandaskan-nilai-nilai-

islam.html. 